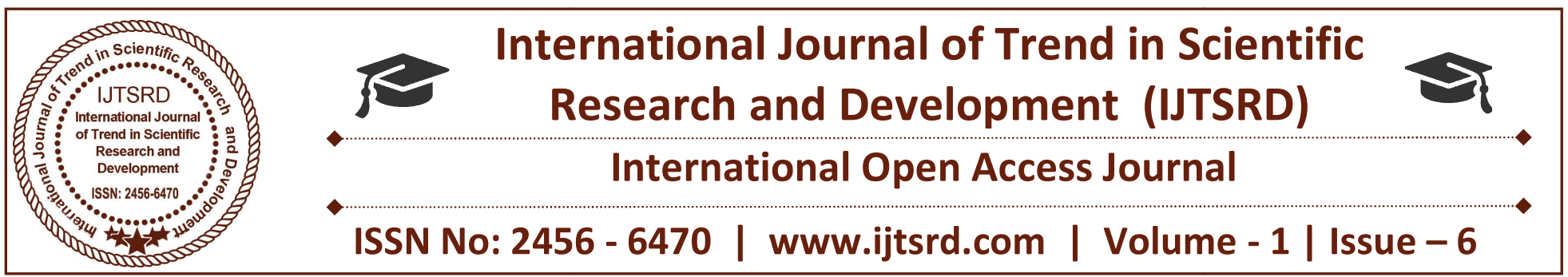

\title{
Significance of Human Resource Development in Globalised Scenario
}

\author{
Donthireddy SivaReddy \\ Research Scholar in Department of Human Resource Management, \\ Andhra University, Visakhapatnam, Andra Pradesh, India
}

\begin{abstract}
The roles and responsibilities of Human Resources departments are transforming as the modern business faces pressures of globalization. The global supply of talent is short of its long-term demand, and the gap is a challenge for employers everywhere. The shortage between the demand and supply of talent is likely to continue to increase, notably for high skilled workers and for the next generation of business executives. Now organizations need to place greater emphasis on attracting human capital rather than financial capital. Global staffing and management of a workforce diverse in culture and language skills and dispersed in different nations are the key goals of global human resources. Only those multinational enterprises willing to adapt their human resource development practices to the changing global labor market conditions will be able to attract and retain high performing employees. Companies with the ability to foresee their business needs and their workforce needs - especially for high skills - will gain the decisive competitive advantage.
\end{abstract}

\section{INTRODUCTION}

The term 'human resource' refers to the knowledge, skills, creative abilities, talents, aptitudes, values and beliefs of an organization's work force. The more important aspects of human resources are aptitudes, values, attitudes and beliefs. But in a given situation, if these vital aspects remain the same, the other aspects of human resources like knowledge, skills, creative abilities, and talents play an important role in deciding the efficiency and effectiveness of an organization's work force. However, enhancement of utilisation and the value of human resources depend on improvement of the aspects like skills, knowledge, creative abilities and talents and moulding of other aspects like values, beliefs, aptitudes and attitudes in accordance with the changing requirements of groups, organization in the globalised scenario.

The effective performance of an organization depends not just on the available resource, but its quality and competence as required by the organization from time to time. The difference between two nations largely depends on the level of quality of human resources. Similarly, the difference in the level of performance of two organizations also depends on utilization value of human resources. Moreover, the efficiency of production process and various areas of management depends to a greater extent on the level of human resource develop assumes significance in view of the fast changing environments and the need for the organization to adopt itself in order to respond to the environmental change.

The changing environmental factors include:

$>$ Unprecedented increase in competition within and outside the country consequent upon the announcement and implementation of economic liberalisation and

> Changing trends towards human resource management and complexities involved in it.

Trends towards market economy are more prevalent in most of the countries including the erstwhile communist countries. These towards marketing economy result in sever competition not only among 
the industries in the globe but also industries with in the nation. This competition allows only the industries strong in all respects to continue in the market and the other industries are forced to with draw from the market.

The attainment of objects of human resource management significantly depends upon the development of human resources. Human resource development is a process by which employees are continuously helped in a planned way to acquire allround capabilities and organizational health. Thus, HRD helps in improving human relations, developing congenial organizational climate in moulding organizational culture and in maximizing employee's contributions in attaining the organizational goals economically and effectively.

In view of the vitality of human resources, the term 'Human Resource Development' has assumed significance. For instance, companies like Reliance industries, Godrej and BPL believe that, the increasing level of productivity is a direct fall out of increased hours spent on training and development of employees. For example, the software major Infosys Company put an astronomical amount of Rs 509 crores in 1997- 98 to the people it employed. In 1998 Motorola India picked up a small, Delhi based company called Usha Termic that makes microchips. One of the preconditions of Motorola before the buyout was that $20 \mathrm{key}$ employees in the Microchip Company would remain there, post-acquisition. Motorola figured that, without the expertise of these 20 people, its acquisition was futile. These companies realised that the willingness of the top management to spend a lot of time hiring and nurturing the best available talent and they have been suitably awarded by the capital market for their efforts. In fact, the union government has also instituted a separate Ministry for the Human Resource Development. Many organizations have either started Human resource Development department or have appointed Human Resource Development managers or at least have strengthened their personnel departments to look after the human resource development functions.

In spite of human resource development boom, there seems to be a lot of misguided thinking about human resource development in several organizations. One such misconception is treating human resource development which is equivalent to training and development. In fact, the main objectives of HRD are, to maximize the utilization of human resources for the achievement of individual and organizational goals, to provide an opportunity and comprehensive frame work for the development of human resources in an organization, to locate, ensure, recognize and develop the constructive mind and an overall personality of the employees, to develop the sense of team spirit and inter team collaborations to develop the organizational health, culture and effectiveness, to develop dynamic human relations and to generate systematic human resource information.

The contribution of human resources for the organizational effectiveness is more significant. Further it is said that human resource development plays significant role in enhancing human resource contribution for congenial customer relations, maximizing profitability in organization etc.

This vitality of human resources to a nation and to an industry depends upon the level of its development. Organizations to be dynamic growth - oriented and fast changing should develop their human resources. It is needless to say that the organization possessing competent human resources grew faster and can be dynamic. Though positive personal policies and programmes motivate the employees by their commitment and loyalty but these efforts cannot keep the organization dynamic and fast changing. Organizations to be dynamic should possess dynamic human resources. Human resources to be dynamic, acquire capabilities continuously adopt the values and beliefs and aptitudes in accordance with the changing requirements of the organizations. Similarly, when employees use their initiative, take risks, experiment, innovative and make things happen, the component human resources can be dynamic in an enabling culture. Thus the organization can develop, change and excel, only if it possess developed human resources. Thus in the globalised scenario HRD plays significant role in making the human resources vital, useful and purposeful.

\section{REFERENCES:}

1. Adler, N.J. (1997) International Dimensions of Organizational Behavior, 3rd edition. Cincinnati: South-Western College Publishing.

2. Adler, N.J. and Ghadar, F (1990)-Strategic Human Resource Management: A Global Perspective', in Pieper, R. (ed.) Human Resource Managementin International Comparison. Berlin: de Gruyter. 
3. BCG and WFPMA (2010) -Creating People Advantage 2010 - How

Companies CanAdapt Their HR Practices for Volatile Times', The Boston

Consulting Group and WorldFederation of People management associations

September.

4. Belcourt, Monica and Kenneth McBey, Strategic Human Resources Planning, Cengage Learning, 2010

5. Friedman T.L. (2004) The World is Flat New York: Farrar, Straus and Giroux

6. Guthridge, Matthew, Asmus B. Komm, and EmilyLawson (2008) -Making talent a strategic pripority“ McKinsey Quarterly, January

7. Hamel, G. and Prahalad, C.K. (1994) Competing for the Future. Boston Mass.: Harvard Business School Press

8. McKinley Global Institute, -The Emerging Global Labor Market: Part I - The Demand for Offshore Talent in Services', (2005)

9. McKinley Global Institute, -The Emerging Global Labor Market: Part II -The Supply of Offshore Talent in Services', (2005)
10. Milliman , J., Von Glinow, M.A. and Nathan, M (1991) Organizational Life Cycles and Strategic International Human Resource Management in Multinational Companies: Implecations for Congruence Theory, Academy of Management Review, 16

11. Pfeffer, J. (1994) -Competitive Advantage Through People' Boston Mass.: Harvard Business School Press.

12. Schuler, R.S. and Jackson, S. (1987) Linking Competitive Strategies with Human Resource Management Practices, Academy of Management Executive, 1

13. Tung, R.L. and Punnett, B.J. (1993) The Relationship of Staffing Practices to Organizational Level Measures of Performance, Personnel Psychology,46: 27-48

14. Ulrich, Dave (1996) Human Resource Champions-The next agenda for adding value and delivering results. Boston, Mass.: Harvard Business School Press.

15. World Economic Forum (2011) - Global Talent Risk - Seven Responses ${ }^{6}$

16. World Migration Report 2010b -An Overview of International Migration Trends 